\title{
BEKAYAT SASAK DI LOMBOK ANTARA KELISANAN DAN KEBERAKSARAAN
}

\author{
BEKAYAT IN LOMBOK \\ ORAL AND LITERACY TRADITION
}

\author{
Made Suyasa \\ Tenaga Pengajar Universitas Muhammadiyah Mataram
}

Tanggal naskah masuk: 17 Juli 2012

Tanggal revisi terakhir: 22 November 2012

\begin{abstract}
Bekayat is a literary tradition of Sasak community in Lombok. This tradition is conducted through tale or poem recitation followed by meaning interpretation which is done in turn by the reciter and theinterpreter (bujangge). Bekayat is a way for Sasaknese to apreciate literary texts. Those texts areorally translated, interpreted, and reviewed deeply, philosphically, and sufistically in order that the text of Bekayat will be meaningfull to human life. The function of Bekayat is not only as medium of religious teaching but aslo as tradition to build good relationship among other people. Oral and literacy tradition are still growing within Indonesian people, both of them can not be separated each other. This condition leads khirografik culture to have its good place as a stage of appreciation of traditional texts. As a stage of appreciation, bekayat are presented fully during the performance. The content of the text related to actually issues - social, politic, economy, culture and out of religious teaching deeds - are elaborated during the performance. This approach of appreciation is focused on how the text is used in religious life, social, and culture.
\end{abstract}

Keywords: bekayat, khirografik, oral tradition, and literacy tradition

\begin{abstract}
Abstrak
Bekayat adalah tradisi sastra masyarakat Sasak di Lombok yang berupa pembacaan hikayat/syair dengan cara menembangkan kemudian diikuti terjemahan dan penafsiran secara bergantian oleh penembang dan pengarti (bujangge).Bekayat merupakan bentuk apresiasi masyarakat Sasak terhadap teks-teks sastra, disitulah teks-teks tulis diterjemahkan, ditafsirkan, dan dikaji secara lisan oleh pelaku bekayat secara lebih dalam, filosofis atau sufistik sehingga teks itu menjadi bermakna bagi kehidupan manusia yang menghasilkan dan yang menggunakannya. Kehadiran bekayat bukan hanya sebagai media dakwah, namun mampu menyatu dengan kehidupan ritual adat keagamaan masyarakat suku Sasak dan membangun silaturrahmi dalam bentuk berkesenian. Kelisanan dan keberaksaraan masih tetap berkembang dalam masyarakat Indonesia karena keduanya saling mendukung, hal ini menjadikan kebudayaan khirografik mendapat tempat yang baik sebagai panggung apresiasi teks-teks tradisional. Bekayat sebagai panggung apresiasi berlangsung sepanjang pertunjukan, mereka berusaha mengangkat isu-isu aktual yang terkait dengan teks baik itu isu sosial, politik, ekonomi, budaya, dan juga praktik-praktik kehidupan yang melnyimpang dari ajaran Islam. Pendekatan dalam praktik apresiasi seperti dalam bekayat menekankan pada bagaimana teks digunakan dalam kehidupan keagamaan, sosial, dan budaya.
\end{abstract}

Kata kunci : bekayat, khirografik, kelisanan, dan keberaksaraan

\section{Pendahuluan}

Bekayat adalah tradisi sastra masyarakat Sasak di Lombok yang berupa pembacaan hikayat/syair dengan cara menembangkan kemudian

diikuti terjemahan dan penafsiran 
secara bergantian oleh penembang dan pengarti (bujangge). Tradisi apresiasi sastra ini memiliki sejarah sastra yang panjang. Data yang ada menunjukkan tradisi bekayat sudah dimulai abad ke16 dan tradisi ini berlanjut sampai sekarang. Peminat bekayat tidak banyak, umumnya para orang tua di pedesaan, yang masih taat pada adat dan kebiasaan masa lalu. Bekayat hadir sebagai media dakwah dan upacara peringatan keagamaan, kemudian terkait dengan keperluan adat digunakan untuk upacara ngurisang (potong rambut bayi), nyiwa' (peringat sembilan hari kematian), perkawinan, dan sunatan. Sejalan dengan kemajuan teknologi,bekayatjuga disiarkan lewat di radio, pengeras suara di Masjid, direkam, dan pernah dilombakan melalui RRI Mataram hingga lomba yang dilaksanakan di lapangan terbuka. Dari waktu ke waktu tradisi bekayat berubah dengan dinamika literasinya tersendiri.

Tradisi bekayat merupakan resitasi,yang dalam praktiknya melibatkan tradisi kelisanan dan keberaksaraan.Tradisi seperti ini masih ada pada beberapa masyarakat suku bangsa di Indonesia.Sebagai negara kepulauan, Indonesia memiliki berbagai suku bangsa yang hidup dan berkembang sejak zaman dahulu. Setiap sukubangsa membawa bahasanya masing-masing, diperkirakan sekitar 700-an bahasa hidup tersebar di berbagai kepulauan di wilayah Indonesia. Suku-suku bangsa ini kemudian membangun peradabannya dalam rangka mempertahankan kehidupannya. Semua itu menjadi bagian dari budaya hidup mereka. Kondisi tersebut telah menjadikan Indonesia sebagai negara yang mempunyai kebhinekaan peradaban terbesar di wilayah Asia Tenggara. Hal ini dilihat dari tradisitradisi yang berkembang dalam masyarakatnya, yakni keragaman tradisi kelisanan dan keberaksaraan.

Era keberaksaraan sudah cukup lama berkembang dalam masyarakat Indonesia, namun kelisanan yang seiring dengan kehidupan masyarakatnya tetap terjaga. Dalam hal ini, tidak semua kegiatan komunikasi dapat tergantikan oleh keberaksaraan. Kedua tradisi tersebut hidup berdampingan dan saling menunjang dalam melayani kepentingan komunikasi pada masyarakatnya. Sweeney menegaskan bahwa, kelisanan dan keberaksaraan merupakan dua hal yang berkaitan: kita dapat melihat kelisanan dalam yang tertulis dan keberaksaraan dalam yang lisan ${ }^{1}$.

Di Indonesia, kelisanan dan keberaksaraan mengalami empat tahap sekaligus, yaitu (1) tahap kelisanan yang cukup murni masih terdapat di berbagai daerah, paling tidak di pelosok-pelosoknya; (2) tahap kebudayaan khirografik yang masih ada, dalam berbagai lingkungan di mana pembacaan naskah sudah lazim dan masih lazim; (3) tahap tipografik, khususnya lewat pendidikan modern; 
(4) tahap elektronik, dengan kelisanan sekunder adalah golongan yang cukup besar masuk tahap ini sebagai golongan terdidik atau sekaligus juga menghayati kebudayaan tipografik (Teeuw) ${ }^{2}$. Dari keempat tahap tersebut kelisanan masih dominan dalam kehidupan masyarakat Indonesia. Pada masyarakat niraksara, kelisanan akan menanggung beban dalam pewarisan kebudayaan. Akan tetapi, pada masyarakat keberaksaraan, kelisanan akan tetap menjadi bagian dari aktivitas komunikasi.

Tradisi kelisanan diartikan sebagai segala wacana yang diucapkan meliputi yang lisan dan yang beraksara atau dikatakan juga sebagai "sistem wacana yang bukan aksara" (Pudentia) $^{3}$. Bertahannya sebuah tradisi lisan-khususnya cerita dan puisikarena kesanggupan tradisi tersebut menyediakan kebutuhan masyarakat pendukungnya terutama dalam hal nilai-nilai yang terkandung di dalamnya dan ketersediaannya media sebagai wadah pelestarian. Nilai-nilai yang ada dirasakan masih relevan dengan kehidupan saat ini. Namun, dalam proses modernisasi masyarakat Indonesia, nilai-nilai dalam tradisi lisan itu akan terus mendapat tantangan. Modernisasi telah membuka keran masuknya ilmu pengetahuan, teknologi, dan peradaban budaya dari masyarakat yang lebih maju melalui berbagai wahana komunikasi. Nilainilai tradisional yang dulunya hidup dan berlaku dalam masyarakat akan terdesak dan tergeser oleh modernisasi.
Sumantri dalam Esten ${ }^{4}$ menyatakan bahwa modernitas itu sendiri adalah suatu konsepsi kebudayaan yang tumbuh dalam peradaban manusia sebagai akibat kemajuan manusia. Karena itulah, kemajuan manusia hendaknya menjadikan modernisasi sebagai nilai dasar yang dalam penerapannya agar sesuai dengan pandangan hidup suatu bangsa atau masyarakat.

Bekayat sebagai media pelestarian dan apresiasi masyarakat Sasak terhadap karya sastra lokal belum sepenuhnya mendapat sambutan positif dari masyarakat pemiliknya, pemerintah, dan para peneliti sastra.Tradisi ini kini hidup terpinggirkan di tengah hiruk-pikuknya kemajuan teknologi komunikasi, sentuhan teknologi sebatas mik pengeras suara masjid ketika pertunjukan bekayat yang menjangkau rumah-rumah penduduk sekitarnya di malam hari. Media seperti radio, televisi, VCD/DVD belum maksimal untuk berpartisipasi dalam menumbuhkembangkan tradisi ini.

Warisan budaya yang berupa teks-teks sastra, sejarah, hukum, agama dalam masyarakat Sasak cukup banyak. Museum Negeri NTB yang kini telah mengoleksi takepan (naskah lontar) lebih dari 1200 buah merupakan peninggalan yang tak ternilai harganya. Sementara naskah dan kitab lainnya masih banyak tersimpan di rumahrumah penduduk, inilah yang kemudian mereka apresiasi dalam bentuk bekayat 
dan pepaosan (pembacaan naskah yang ditembangkan disertai terjemahan dan penafsiran, yang serupa geguritan di Bali dan macapatan di Jawa). Tradisi penulisan naskah pada masyarakat Sasak tidak jauh beda dengan masyarakat Jawa dan Bali baik dari segi huruf yang digunakan dan tradisi penulisan yang dikembangkan. Era keberaksaraan pada masyarakat Sasak merupakan awal peradaban pengembangan ilmu pengetahuan baik di bidang hukum, agama, sastra, dan filsafat.

Masyarakat sering terlena terhadap kandungan isi atau plot yang ada dalam teks baik lisan maupun tulis, namun mereka tak sampai pada pertanyaan-pertanyaan "ada apa di balik teks", mengapa teks itu diciptakan, untuk apa, dan berbagai pertanyaan lainnya. Pertanyaanpertanyaan tersebut sebagai bentuk apresiasi penikmatnya, dalam masyarakat Sasak apresiasi tersebut terwadahi dalam bekayat. Disitulah teks-teks tulis diterjemahkan, ditafsirkan, dan dikaji secara lisan oleh pelaku bekayat secara lebih dalam, filosofis atau sufistik sehingga teks itu menjadi bermakna bagi kehidupan manusia yang menghasilkan dan yang menggunakannya.

\section{Perkembangan Bekayat}

Bekayat diperkirakan mulai berkembang ketika penyebaran agama Islam tahap kedua yang dibawa oleh para mubaliq dari daerah Semenanjung
Melayu melalui Goa.Pembacaan hikayat dijadikan sebagai media dakwah oleh para mubaliq dalam penyebaran agama Islam.Sejak kapan bekayat ini dilaksanakan sebagai bagian dari ritual adat keagamaan pada masyarakat suku Sasak di Lombok perlu ditelusuri lebih jauh kesejarahannya.

Tradisi pembacaan hikayat pada suku Sasak di Lombok berbeda dengan di daerah lain seperti di Semenanjung Melayu, dimana hikayat yang dibacakan atau dilisankan dengan irama tertentu tanpa ada terjemahan dan penafsiran isi. Besar kemungkinan, bekayat adalah produk budaya suku Sasak yang merupakan bentuk peniruan dari pepaosan yang sudah berkembang jauh sebelum hikayat Melayu masuk ke Lombok.

Kehadiran bekayat bukan hanya sebagai media dakwah, namun mampu menyatu dengan kehidupan ritual adat keagamaan masyarakat suku Sasak dan membangun silaturahmi dalam bentuk berkesenian. Bekayat menjadi bagian yang tak terpisahkan dalam berbagai ritual adat keagamaan dan diyakini pula bahwa setiap pembacaan hikayat membawa berkah dan keselamatan bagi yang melaksanakan dan yang mendengarkannya. Sejalan dengan kemajuan masyarakat di bidang pendidikan, masuknya pengaruh modernitas, dan berbagai paham Islam puritan, menjadikan bekayat dipandang terkebelakang, bid'ah, dan khurafat. Sejalan dengan itu, Hamid 
menyatakan bahwa karya kesusastraan Indonesia memiliki pengaruh Islam karena dianggap bid'ah karena banyak didapati unsur-unsur rekaan yang digambarkannya sebagai suatu pemikiran Islam yang sejati. Tradisitradisi lisan yang dikaitkan dengan agama adalah warisan dari masa lalu yang dianggap mengandung sinkretis.

Arus modernisasi di bidang teknologi komunikasi telah menggeser beberapa tradisi yang sebelumnya sebagai pelengkap ritual dan juga sebagai media hiburan. Hiburan masyarakat kini sudah banyak tergantikan oleh berbagai bentuk baik modern maupun tradisional yang tersedia dalam bentuk rekaman seperti kaset dan VCD/DVD. Hal ini tentu mendatangkan keuntungan dan kerugian.Kaset dan VCD/DVD dapat memberikan keuntungan karena menyebar keberbagai tempat dan dikenal banyak orang. Namun semua itu telah meniadakan berbagai pertunjukan yang biasanya juga dijadikan media hiburan untuk dinikmati secara bersama-sama.

Fenomena di atas telah berdampak pada perkembangan bekayat dimana masyarakat yang menekuni profesi ini semakin hari semakin berkurang. Sekarang hanya dilakukan oleh sebagian kecil masyarakat yang hanya terdiri atas golongan orang tua sebagai tokoh agama atau tokoh masyarakat (Acim dan Ahyar) ${ }^{6}$. Di samping itu, bekayat berangsur-angsur ditinggalkan oleh masyarakatnya, sehingga hanya berkembang pada komunitas tertentu saja dan dipertunjukkan pada kesempatan tertentu saja. Hal ini tentu sangat memprihatinkan. Untuk itu, perlu pula ditelusuri vitalitas (daya hidupnya) serta sikap masyarakatnya terhadap keberadaan bekayat dalam masyarakat suku Sasak di Lombok sekarang ini.

Gelombang modernisasi dalam teknologi komunikasi seperti radio, televisi yang melanda kehidupan masyarakat termasuk masyarakat Sasak belum mampu untuk dimanfaatkan sebagai panggung dalam mengangkat dan memajukan sastra Sasak. Kemajuan teknologi berupa alat komunikasi modern saat ini hanya menjadi ancaman bagi perkembangan tradisi kelisanan seperti bekayat. RRI Mataram sebagai stasiun radio pemerintah hanya menyiarkan hasilhasil rekaman yang dibuat beberapa puluh tahun yang lalu karena terbatasnya anggaran tidak mampu untuk mendokumentasikan hasil-hasil budaya dalam bentuk kelisanan. Pada tradisi kelisanan akan lebih cepat mengalami kepunahan sejalan dengan ketiadaan pelaku tradisi tersebut.Pemerintah daerah di pulau Lombok hampir tidak mempunyai program tetap dalam pembinaan dan lomba-lomba untuk tradisi-tradisi kelisanan. Miskinnya perhatian berbagai pihak terhadap perkembangan tradisi lisan seperti bekayat hanya akan 
membuat tradisi ini menjadi semakin terpuruk.

Gambaran di atas menyiratkan bahwa bekayat sebagai produk budaya masyarakat Sasak dan cermin berpikir serta berperilaku masyarakatnya perlu mendapat perhatian semua pihak. Bekayat perlu ditelusuri dari berbagai aspek mulai dari sejarah perkembangannya, struktur teks, transformasi, serta pergeseran fungsi dan makna dalam masyarakat Sasak. Melalui penelusuran dan pengajian akan memungkinkan untuk melihatnya sebagai produk dari sebuah tradisi lisan yang utuh dalam kehidupan masyarakat Sasak.

\section{Refleksi Kelisanan dan}

\section{Keberaksaraan}

Masyarakat Sasak adalah masyarakat yang berbudaya, karena banyak warisan budaya yang kita saksikan dalam bentuk artefak, pengetahuan, dan perilaku tata kehidupan. Generasi muda sebagai pewaris budaya tidak cukup dengan menjaga dan menghormati warisan tersebut, namun sudah seharusnya untuk mempelajari dan mengungkapkan hal-hal yang ada di dalamnya. Semua ituakan sangat berguna dalam menyingkap kehidupan masa lalu dan untuk menata kehidupan ke depan yang lebih baik. Hasil-hasil karya sastra lisan dan tulis menurut pandangan sarjana barat menekankan bahwa teks Indonesia berguna mungkin dalam teks terdapat informasi yang berguna bagi ahli sejarah, linguistik, antropologi atau mahasiswa teologia (Robson) ${ }^{7}$.

Sikap dan pandangan kita (masyarakat Indonesia) terhadap warisan budaya berupa teks, sering dianggap sebagai barang pusaka yang 'pelestariannya' dilakukan dengan berbagai cara menurut tradisi daerah. Pelestarian teks dalam masyarakat Sasak tidak jauh beda dengan masyarakat di Jawa dan Bali yakni tradisi pembacaan teks dengan cara menembangkan yang dikuti terjemahan dan penafsiran dalam bahasa Sasak. Tradisi ini adalah sebuah kegiatan bersastra yang melibatkan kelompok pencinta sastra yang terdiri ataspemaca (pembaca), bujangge atau tukang cerite (penerjemah), penyarup (pengikut tembang), dan penonton/pendengar. Kegiatan ini menjadi panggung apresiasi masyarakat pencinta sastra tradisional dari tingkat pemahaman hingga penikmatan. Di panggung inilah teks dibahas, diulas, dimaknai, dan tentu diteladani semua hasil pergulatan mereka terhadap makna yang diperoleh.

Berangkat dari tradisi yang dilakukan oleh masyarakat Sasak dalam bentuk bekayat sebagaimana dijelaskan di atas, maka upaya sesungguhnya yang dilakukan dalam konteks ini adalah membaca dan mengaji teks. Kita memang cukup lama tenggelam dalam kelisanan sehinga tradisi membaca menjadi periode baru dalam sejarah pemikiran manusia. 
Sebagian besar masyarakat kita masih lebih senang memperoleh informasi lisan daripada harus membaca, kebiasaan ini akan lebih mengkhawatirkan apabila telah menjangkiti kaum intelektual. Kemajuan teknologi komunikasi telah memberi ruang terhadap menurunnya minat baca, sebab banyak ilmu pengetahuan dan informasi disampaikan melalui media elektronik sebagai bentuk kelisanan kedua (secondery orality).

Tradisi membaca memang tidak dapat dilepaskan dengan tradisi penulisan, keduanya dapat terjadi secara bersamaan. Masyarakat Sasak dalam perjalanan sejarah penulisan teks sudah cukup lama, sejak masuknya pengaruh Majapahit masyarakat mulai bersentuhan dengan peradaban baru dalam tradisi keberaksaraan. Berkembangnya tradisi ini terbukti dari hasil penulisan naskah yang dilakukan oleh para pujangga Sasak, dan mencapai puncaknya antara tahun 1700-1800-an. Masuknya Islam ke pulau Lombok telah diikuti oleh masuknya perdaban-peradaban baru yang mengajarkan dan mengarahkan pada tradisi membaca, mulailah naskah-naskah sastra Jawa-Islam dan naskah keagamaan yang dibawa oleh para mubaliq dari Jawa dan Semenanjung Melayu memasuki tanah Sasak.

Menurut Jamaluddin $^{8}$ berkembangnya budaya tulis dalam masyarakat Sasak dipengaruhi oleh beberapa faktor, 1) kehadiran Islam sebagai sebuah ajaran agama dan budaya yang tidak ditrasformasikan hanya dengan tradisi lisan; 2) adanya dukungan yang kuat dari kalangan istana kepada para intelektual muslim untuk menulis, sehingga dihasilkannya beberapa penulisan seperti babad serta karya-karya sastra; 3) faktor budaya memegang peranan penting terhadap banyaknya karya intelektual muslim karena berkembangnya tradisi pembacaan naskah pada masyarakat Sasak.

Tradisi pembacaan naskah seperti hikayat dan syair, ketika penyebaran Islam di Lombok dilakukan oleh para mubaliq dan hingga memasuki pesantren-pesantren sebagai salah satu metode dalam pembelajaran Islam. Pembacaan naskah pada masyarakat Sasak sekarang ini hanya dilakukan di bulan Mi'raj dan Maulid, dan masyarakat juga biasanya merangkaikan dengan melaksanakan upacara adat seperti khitan dan ngurisang (potong rambut) anak-anak mereka, karena di bulan itu diyakini sebagai bulan yang penuh berkah. Naskah yang dibaca pada saat peringatan keagamaan dan adat biasanya hikayat Nabi-nabi (Qisas alAmbiya), Qamar al-Zaman, Jafar Sadiq, Nabi Bercukur, Ali Hanafiyah, dan Nabi Yusuf. Naskah Sasak ada juga yang dibacakan untuk keperluan membayar kaul dan pengobatan (sympatetic-megic), seperti naskah Selandir untuk anak yang belum dapat 
berjalan, naskah Indar Jaya, dibacakan untuk anak yang sulit berbicara, dan naskah Indrabangsawan, untuk anak yang dungu. Naskah-naskah yang akan dibaca sebelumnya diawali dengan prosesi tertentu secara adat dan juga pada akhir pembacaan. Pembacaan naskah selalu dilakukan pada malam hari setelah Isa' dan berakhir sebelum subuh.

Naskah yang dibaca dalam bekayat merupakan naskah keagamaan yang bertuliskan Arab Melayu dan ada yang bertuliskan huruf Jejawan (huruf Sasak), tradisi ini dilakukan sebagai bentuk apresiasi masyarakat terhadap teks di samping penyebaran isi teks pada masyarakat karena nilai-nilai yang terkandung di dalamnya lebih bersifat religius. Tradisi bekayat sebagai tahap kebudayaan khirografik, di mana berkembang bersamaan dengan berkembangnya tradisi penulisan naskah atau kebudayaan manuskrip. Ong seperti yang dikutip Teeuw ${ }^{9}$ mengatakan khirografik merupakan tahap kebudayaan manuskrip, khususnya dengan fungsi aural yang masih kuat. Kedua tradisi tersebut masih tetap berkembang dalam masyarakat Indonesia karena keduanya saling mendukung, hal ini menjadikan kebudayaan khirografik mendapat tempat yang baik sebagai panggung apresiasi teks-teks tradisional.

\section{Bekayat sebagai Panggung Apresiasi}

Perkembangan bekayat beberapa dekade terakhir memang mengalami masa suram, data yang ada menunjukkan penurunan minat penekun/pelaku bekayat di kampungkampung yang dulunya terkenal sebagai gudangnya pelaku-pelaku yang cukup terkenal, seperti di Desa Mapak, Lombok Barat jumlah penekun sudah tinggal lima orang yang sebelum ada puluhan orang penekun. Proses regenerasi tampaknya tidak berhasil menarik minat generasi muda untuk menekuni tradisi ini sehingga pelaku bekayat sekarang ini rata-rata berusia di atas 50 tahun. Di samping itu, gejala umum menunjukkan bahwa masyarakat tidak lagi menjadikan bekayat sebagai bagian dari upacara adat yang mereka laksanakan. Mereka lebih tertarik menghadirkan hiburan modern seperti pertunjukan musik dangdut. Fenomena lain juga terjadi pada minat penikmat/penonton yang tidak lagi tertarik menyaksikan tradisi ini, pertunjukan semalam suntuk praktis hanya dihadiri oleh para tukang bekayat dan penanggap (tuan rumah). Para tukang bekayat tetap semangat karena mereka beranggapan yang dipertunjukkan malam itu didengar oleh masyarakat sekitarnya melalui corong pengeras suara. Membaca naskah hikayat bagi mereka merupakan amalan dan sebuah perintah dari Allah SWT. Gejala terakhir inilah yang tampaknya masih menguatkan 
semangat mereka untuk tetap memelihara tradisi ini sampai sekarang.

Di sisi lain, secara akademis kehadiran bekayat dapat merupakan sebuah panggung apresiasi yang akan membuka wawasan di antara mereka, bukan sekedar menjadikannya sebagai hiburan tetapi media pengajian sastra secara serius. Kupasan yang mereka lakukan mulai dari struktur cerita, kandungan nilai, unsur semantik hingga implementasinya dalam kehidupan nyata. Apresiasi seperti ini memang tidak didasari oleh teori dalam ilmu sastra. Namun kajian mereka jauh lebih menyentuh pada perbandingan praktik-praktik kehidupan dalam cerita dengan yang ada di alam nyata.

Bekayat sebagai panggung apresiasi berlangsung sepanjang pertunjukan. Mereka berusaha mengangkat isu-isu aktual yang terkait dengan teks baik itu isu sosial, politik, ekonomi, budaya, dan juga praktikpraktik kehidupan yang melanggar ajaran Islam. Pendekatan dalam praktik apresiasi seperti dalam bekayatmenekankan pada bagaimana teks digunakan dalam kehidupan keagamaan, sosial, dan budaya. Tradisi bekayat dalam konteks ini tidak saja berarti penting dalam kehidupan adat keagamaan masyarakat Sasak, tetapi dapat memberikan kontribusi yang cukup penting dalam proses produksi pengetahuan sosial budaya dan humaniora. Oleh karena itu tugas para akademisi untuk masuk ke dalamnya melakukan penelitian terhadap teks- teks sastra Sasak dan tradisi ikutannya. Lewat ruang itulah nantinya kita dapat mengungkap berbagai hal mulai dari teks sebagai sumber sejarah, teks sebagai gambaran sosial budaya masyarakat, dan teks sebagai alat untuk melegitimasi kekuasaan atau alat untuk memperjuangkan ideologi tertentu. Berbagai pengetahuan bisa kita dapatkan melalui teks terutama teks sastra. Itulah sebabnya tiada pernah selesainya teks sastra itu dibahas karena ia tetap aktual dalam tinjauan kaca mata yang berbeda-beda.

\section{Simpulan}

Tulisan ini dari awal telah mengajak untuk menimbang keberadaan pengalaman manusia dalam perjalanannya, yakni dalam kelisanan dan keberaksaraan. Masyarakat Indonesia dengan setia telah memelihara keduanya dan dipraktikkan dalam kehidupan berkesenian seperti bekayat dalam masyarakat Sasak. Tradisi ini masih bertahan sampai saat ini terutama dalam peringatan $M i{ }^{\prime} r a j$ dan Maulid serta upacara adat lainnya.Namun proses regerasi tradisi ini sangat lambat dan kini sudah pada kondisi mengkhawatirkan karena terbatasnya orang yang mau menekuninya, gejala ini disebabkan oleh kemajuan pendidikan, arus teknologi komunikasi yang membawa informasi yang jauh lebih menarik untuk ditekuni. Dalam masyarakat modern yang pragmatisme global menurut Darma Putra ${ }^{10}$ ditandai dengan 
prioritas pada pemenuhan kebutuhan materi dan kegandrungan pada hal-hal yang modern.

Bekayat dalam masyarakat Sasak selain sebagai media dakwah dan pelengkap kegiatan adat keagamaan, kini sebagai panggung apresiasi dalam mengaji teks-teks klasik dalam rangka mendalami kandungan yang ada dalam teks. Pendekatan dalam praktik apresiasi seperti dalam bekayat lebih menekankan pada penggunaan teks dalam kehidupan keagamaan, sosial, dan budaya. Tradisi bekayat dalam konteks ini tidak saja berarti penting dalam kehidupan adat keagamaan masyarakat Sasak, tetapi dapat memberikan kontribusi yang cukup penting dalam proses produksi pengetahuan sosial budaya dan humaniora.

\section{DAFTAR PUSTAKA}

${ }^{1}$ Sweeney, Amin. 1999. "Kajian Tradisi Lisan dan Pembentukan Wacana Kebudayaan". Makalah dalam Seminar Internasional Tradisi Lisan di Jakarta.

${ }^{2}$ Teeuw, A. 1994. Indonesia Antara Kelisanan dan Keberaksaraan. Jakarta: Pustaka Jaya.

${ }^{3}$ Pudentia, M.P.S.S. 1990. Transpormasi Sastra Analisis Atas Cerita Rakyat Lutung Kasarung. Jakarta: Balai Pustaka.

${ }^{4}$ Esten, Mursal. 1999. Kajian Transformasi Budaya. Bandung: Angkasa.

${ }^{5}$ Hamid, Ismail. 1989. Kesusastraan Indonesia Lama Bercorak Islam. Jakarta: Pustaka Al-Husna.

${ }^{6}$ Acim, Subhan Abdullah dan Ahyar. 2011. "Tradisi Nyaer Kitab Kifayat Al-Muhtaj sebagai Media Dakwah di Lombok" (dalam Jurnal Penelitian Keislaman No. 2, Vol.7, Juni 2011, hlm. 421-436).

${ }^{7}$ Robson, S.O.1994. Prinsip-prinsip Filologi Indonesia. Jakarta: Pusat Pembinaan dan Pengembangan Bahasa bekerja sama dengan Universitas Leiden.

${ }^{8}$ Jamaluddin. 2011. "Islam Sasak: Sejarah Sosial Keagamaan Di Lombok (Abad XVI-XIX)” (dalam Jurnal INDO-ISLAMIKA, Volume 1, Nomor 1, 2011/1432 H (hal 63-88).

${ }^{9}$ Teeuw, A. 1994. Indonesia Antara Kelisanan dan Keberaksaraan. Jakarta: Pustaka Jaya. 
46|Mabasan, Vol. 6 No. 2, Juli-Desember 2012

${ }^{10}$ Putra, Darma I Nyoman. 2011. "Mungkinkah Menganggap Akhir Abad ke-20 Sastra Bali Memasuki Sebuah Era Keemasan?" (dalam Jurnal Kajian Bali, Volume 01, Nomor 02, Oktober 2011, Halaman 159-185). 